\title{
Environmental Management on Natural River Based on Water Quality Deterioration in Terengganu River Basin, Terengganu, Malaysia
}

\author{
Nurul Hafizza Mohd Amran', Mohd Khairul Amri Kamarudin ${ }^{1,2 *}$, Noorjima Abd Wahab ${ }^{2}$, Muhammad Hafiz Md \\ Saad $^{2,3}$, Mohd Hafiz Rosli ${ }^{4}$, Mohd Armi Abu Samah ${ }^{5}$, Nor Bakhiah Baharim ${ }^{6}$, Nurul Asma Ezzatee Mohd Razak ${ }^{1}$, \\ Syazni Jusoh ${ }^{1}$
}

\begin{abstract}
${ }^{I}$ Faculty of Applied Social Sciences, Universiti Sultan Zainal Abidin, Gong Badak Campus, 21300 Kuala Nerus, Terengganu, Malaysia ${ }^{2}$ East Coast Environmental Research Institute (ESERI), Universiti Sultan Zainal Abidin, Gong Badak Campus, 21300 Kuala Nerus, Terengganu, Malaysia

${ }^{3}$ AB Bakti Enterprise, Lot 27215 Kg. Gong Kuin 2, Jalan Tok Jembal, 21300 Kuala Nerus, Terengganu, Malaysia

${ }^{4}$ Department of Environmental Sciences, Faculty of Environmental Studies, Universiti Putra Malaysia, 43400 Serdang, Malaysia

${ }^{5}$ Kulliyyah of Science, International Islamic University Malaysia, 25200 Kuantan, Pahang, Malaysia

${ }^{6}$ School of Marine and Environmental Sciences, Universiti Malaysia Terengganu, 21030, Kuala Nerus, Terengganu, Malaysia

*Corresponding author E-mail: mkhairulamri@unisza.edu.my
\end{abstract}

\begin{abstract}
This study is aimed to look at the level of water quality deterioration in Terengganu River Basin. Environmental management studies on the deterioration of water quality in Terengganu River Basin have been using data collection and analysis methods. The Gravimetric method was used to analysis the TSS measured in $\mathrm{mg} / \mathrm{L}$. $250 \mathrm{ml}$ water samples was needed for each study area (each station). All preparation and preservation of the samples are in accordance with standard procedures provided by the American Public Health Society (APHA) and United States Environmental Protection Agency (USEPA). The results show that Terengganu River Basin is classified in level III that is contaminated. The Terengganu River Basin is contaminated at the downstream to the middle of the river due to anthropogenic activity. Moreover, the results indicate that the amount of AN and TSS is higher and is a major contributor to the deterioration of water quality in the Terengganu River Basin. Management of water resources should be improved and noted. This study has proposed several steps in managing water resources such as settlement of land use solutions, regulatory methods, river quality monitoring programs, minimizing waste, wall construction, the use of Geographic Information System (GIS) and legislative measures.
\end{abstract}

Keywords: Terengganu River Basin; America; mitigation methods; Geography Information System (GIS).

\section{Introduction}

Water resources are one of the most important elements in all aspects of life in the world or for the development of an area. Malaysia is a country rich in natural water resources. This is because, Malaysia has a southwestern and northeastern monsoon that causes the country to average an average annual rainfall of more than $2500 \mathrm{~mm}$. From annual water resources recorded the total land mass of $330,000 \mathrm{~km}^{2}$ to 990 billion $\mathrm{m}^{3}$. According [1,2], $7 \%$ or 64 billion $\mathrm{m}^{3}$ of the total has drained underground water and $36 \%$ or 360 billion $\mathrm{m}^{3}$ have returned to the atmosphere known as evapotranspiration. There are plenty of water sources that can be found, namely river water, waterfalls, seawater and so on. The river is one of the main water sources and has many uses. Among the uses of the river are water supply for agricultural, beverage, industrial, tourism and hydroelectric sources. Water resource management in the river requires systematic management to provide quality water resources. Many planning on the development of water resources management has been conducted to address water quality problems. Among them is the concept of environmental flows. This concept has been specifically designed to pro- tect the aquatic downstream from danger [3]. The importance of the river as the main source of water has led to this study.

The clean and good of water quality requirements are essential for a particular area, especially for communities living in the Terengganu River Basin. The systematic water resource management is needed to reduce the cost of treatment, preventing leakage of pipes that will result in water degradation and maintaining water distribution to the community [4]. The monitoring of the Water Quality Index (WQI) is one of the methods to assess the quality and health of all rivers. Furthermore, studies on water quality index have been conducted by many researchers and are aimed at creating various water management systems such as river, lagoon, lakes and beach systems [5-8]. In this regard, the Department of Environment has classified rivers into a few classes such as class I, II, III, IV and V, based on the National Water Quality Standard (NWQS) and WQI. This is one of indicator to measure the quality of water and to detect water pollution (Table 1).

The context of environmental sustainability has been considered for environmental flows in Malaysia [9]. This is a fundamental principle in implementing development and finding ways to stabilize water use as well as to compete with environmental protection. Multi-criteria analysis is one of the important tools for ap- 
proach in the process of water allocation and environmental flow assessment is a method for measuring environmental criteria [10]. The DOE in Malaysia has operated a total of 146 river basins and has more than 1,000 river water quality monitoring stations manually and automatically. In addition, the Department of Irrigation and Drainage (DID) as well as agencies in all states also monitor water quality. This is the main method that is implemented to see the water quality level. In this regard, the quality of the water will be monitored by the NWQS.

Table 1: National Water Quality Standards (NWQS) for Malaysia [11]

\begin{tabular}{|c|c|c|c|c|c|c|}
\hline Parameter & \multicolumn{7}{|c|}{ Class } \\
\hline & Unit & I & II & III & IV & V \\
\hline PH & - & $>7$ & $6-7$ & $5-6$ & $<5$ & $>5$ \\
\hline DO & $\mathrm{mg} / \mathrm{L}$ & $>7$ & $5-7$ & $3-5$ & $1-3$ & $<1$ \\
\hline BOD & $\mathrm{mg} / \mathrm{L}$ & $<1$ & $1-3$ & $3-6$ & $6-12$ & $>12$ \\
\hline $\mathrm{COD}$ & $\mathrm{mg} / \mathrm{L}$ & $<10$ & $10-25$ & $25-50$ & $50-$ & $>100$ \\
& & & & & 100 & \\
\hline TSS & $\mathrm{mg} / \mathrm{L}$ & $<25$ & $25-30$ & $50-$ & $150-$ & $>300$ \\
& & & & 150 & 300 & \\
\hline AN & $\mathrm{mg} / \mathrm{L}$ & $<0.1$ & $0.1-$ & $0.3-$ & $0.9-$ & $>2.7$ \\
& & & 0.3 & 0.9 & 2.7 & \\
\hline Water Quality & & $<92.7$ & $76.5-$ & $51.9-$ & $31.0-$ & $>31.0$ \\
Index (WQI) & & & 92.7 & 76.5 & 51.9 & \\
\hline
\end{tabular}

\begin{tabular}{|c|c|}
\hline Class I & $\begin{array}{l}\text { Conservation of natural environment } \\
\text { Water supply I - Practically no treatment necessary } \\
\text { Fishery I - Very sensitive aquatic species }\end{array}$ \\
\hline Class IIA & $\begin{array}{l}\text { Water supply II - Conventional treatment required } \\
\text { Fishery II - Sensitive aquatic species }\end{array}$ \\
\hline Class IIB & Recreational use with body contact \\
\hline Class III & $\begin{array}{l}\text { Water supply III - Extensive treatment required } \\
\text { Fishery III - Common of economic value and tolerant spe- } \\
\text { cies; livestock drinking }\end{array}$ \\
\hline Class IV & Irrigation \\
\hline Class V & None of the above \\
\hline
\end{tabular}

\section{Methodology}

\subsection{Study Area (Terengganu River Basin)}

The study was conducted around the Terengganu River Basin. Terengganu is a rich country with water resources. Terengganu has eleven main river basins, Terengganu River, Kemaman River, Dungun River, Besut River, Setiu River, Paka River, Marang River, Keluang Besar River, Mercang River, Kertih River and Ibai River. The main tributaries in Terengganu are Berang River, Nerus River, Telemung River and Tersat River and have $5000 \mathrm{~km}^{2}$ catchment area as a whole. The river basin is a surface water runoff area where water sources will flow directly to the rivers, rivers, lakes and seas [12, 13]. Terengganu River Basin is located on the East Coast of Peninsular Malaysia (40 41' - 50 20'N, 102031' $10309^{\prime} \mathrm{E}$ ) and has a tropical rainforest climate with humid temperatures throughout the year. Fig. 1 shows the locations for sampling station at the Terengganu River Basin. The water samples were collected from 29 different predetermined sampling stations from downstream to upstream area along Terengganu River Basin (Fig. 2).

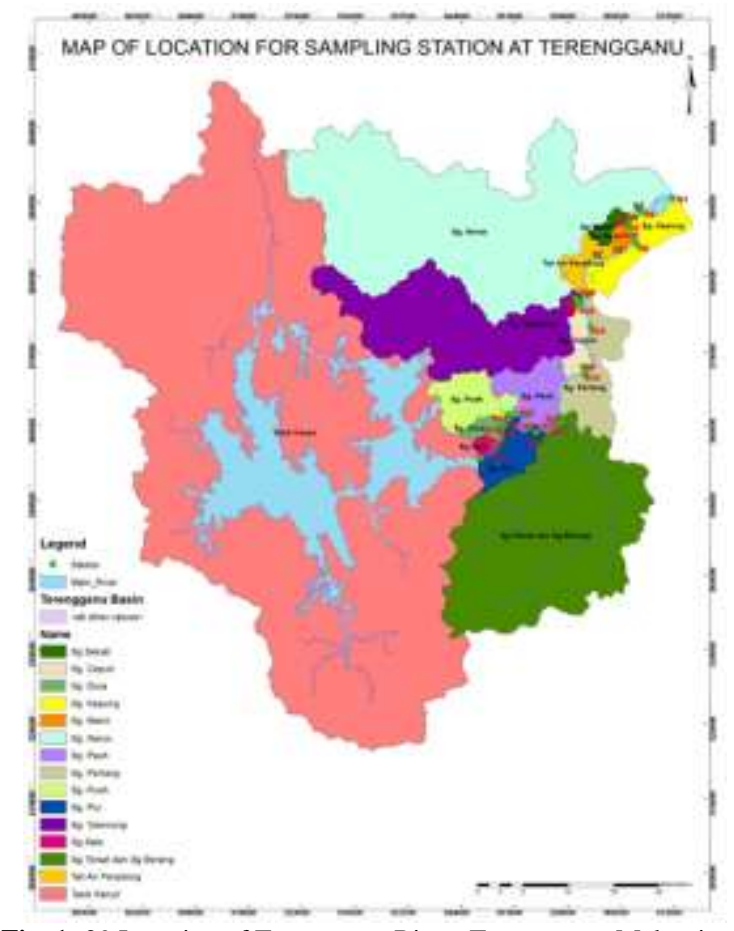

Fig. 1: 29 Location of Terengganu River, Terengganu, Malaysia

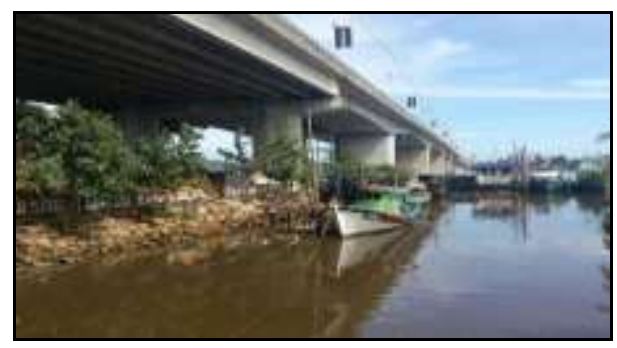

(a)

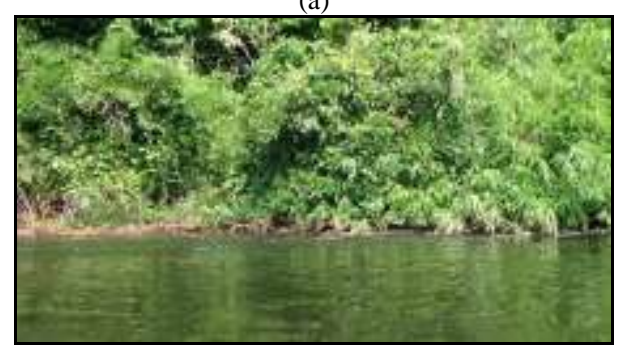

(b)

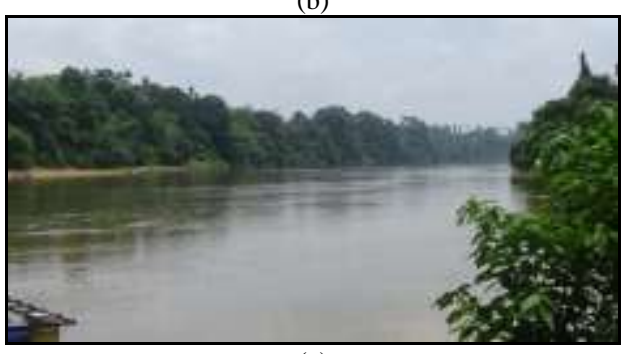

(c)

Fig. 2: Study includes include (a) Downstream, and (b) Middle stream (c) Upstream

The average annual air temperature in the state of Terengganu is between 26 and $28^{\circ} \mathrm{C}$ and receives average rainfall of about 3300 $\mathrm{mm}$. Normally, in March to November it will experience the northeast monsoon season, which is heavy rain. From the secondary findings proved that the total annual rainfall distribution trends at the Terengganu River Basin ranged $2000 \mathrm{~mm}$ (January) to 6000 mm (December) every year from 2001 until 2010 (Fig. 3). The secondary findings indicate that the trend in the study area has significant changes in water quality level. During this season, the study area could be considered as the wettest region since all rainfall indices tested are higher than in other neighbouring state of 
the Peninsular. Malaysia is one of countries receive are average rainfall of more than $2000 \mathrm{~mm}$ per annum. The distribution of rainfall in Terengganu from 2001 until 2010 showed the maximum of intensity rainfall during November until January every year. The total annual rainy days in the study area ranged from 130 to 197 with an average of 175 days/year or 15 days/month. The highest total number of rainy days were obtained at Kampung La (T2 5524001) and Ulu Setiu (T9 542600) especially on November until January respectively. The highest number of rainy days per month (16 days) was recorded during the wet season in 2006 (December), while February and April 2001 until 2010 recorded the lowest number of rainy days.

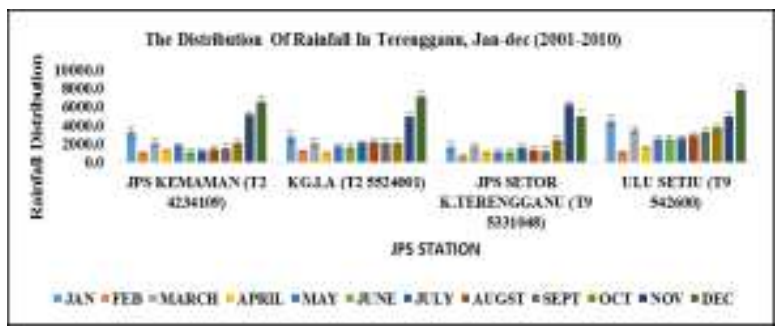

Fig. 3: Annual Rainfall Distribution Trends at the Terengganu River Basin Ranged (Jabatan Pengaliran dan Saliran Malaysia (JPS) dan Jabatan Meteorologi Malaysia (Malaysian Meteorological Department) (MMD))

\subsection{Research Methodology}

In this study, it requires a deep and systematic understanding of water resources management. This is aimed at achieving the goals and objectives of planning water resources development in the Terengganu river basin as well as addressing issues in the contex of water quality when water resource management planning is underway. The method used in this study is data collection and analysis. All the sample preparation and preservations conducted were following on the standard procedures provided by APHA and USEPA Methods. The Gravimetric Method was used to analysis the TSS measured in $\mathrm{mg} / \mathrm{L}$. In lab analysis about $250 \mathrm{ml} \mathrm{wa-}$ ter sample was needed for each study area (each station). The measurements of in situ parameters were $\mathrm{pH}$, temperature, Ammoniacal Nitrogen (AN), and Dissolved Oxygen (DO). All of these parameters were determined by using the water-quality Multiprobe Model DO meter YSI 58. This multiprobe meter was calibrated before field sampling. Then, the water sample for Chemical Oxygen Demand (COD) were preserved, kept at low temperature prior transportation to the laboratory and analyzed using DR 2800 Portable Spectrophotometer. Laboratory analysis was performed based on the standard method of analysis (APHA 1998) [14, 15].

\section{Results and Discussion}

\subsection{Water Quality Status in Terengganu River Basin}

Water resource management is an important aspect that needs to be addressed. This is because water resources management involves all aspects of beneficial water use. In this regard, the management of water resources in the Terengganu River Basin needs to be improved. Based on the results of the analysis, the water quality from the upstream to downstream of the Terengganu River was deteriorated. Table 2 shows that significant variable inputs with linear relationships to predict WQI in the Terengganu River Basin. This study also uses one-to-one method or input interests. This method is used to determine whether significant variables ( $\mathrm{p}$ $<0.05$ ) are caused by linear correlation between input-output. The highest percentage was AN $(66.2 \%)$ and followed by COD (20.75\%). The AN and CO parameters are high in the Terengganu River Basin due to the anthropogenic activity around the river basin and subsequently polluted Terengganu River Basin. At the same time, the table above also shows the lowest percent is DO $(0.34 \%)$ and $\mathrm{pH}(0.15 \%)$. In addition, parameter analysis also showed that AN (50.31\%) and TSS (48.03\%) percent were the highest compared to other parameters.

Based on the analysis, AN and TSS are the main parameters that contribute to the Terengganu River Basin, especially in the upstream and downstream areas. In this regard, there are several factors that cause the quality of water in the Terengganu River Basin to be polluted and deteriorated. Among the factors are the research station adjacent to the disposal of municipal waste, industry, agriculture and some untreated aquaculture activities into the Terengganu river system and cause the results of the analysis to be affected. In addition, the decomposition process found that the $\mathrm{pH}$ and DO values were low and the values for TSS and AN were high $[16,17]$. The $\mathrm{pH}$ and $\mathrm{DO}$ values are high because they contain organic content derived from these activities. In order to prevent Terengganu's water quality being polluted, river water management measures should be enhanced in Terengganu River Ba$\sin$.

Table 2: Input importance variables in linear relationship to predict WQI at Terengganu River Basin, 2016

\begin{tabular}{|c|c|c|c|}
\hline \multicolumn{4}{|c|}{ R-Square Reference $=0.9737$} \\
Variable & $\begin{array}{c}\text { R-Square } \\
\text { Leave Variable }\end{array}$ & $\begin{array}{c}\text { R-Square } \\
\text { Difference }\end{array}$ & $\begin{array}{c}\text { Percent } \\
\text { Contribution }\end{array}$ \\
\hline DO & 0.9718 & 0.0019 & 0.34 \\
\hline BOD & 0.9499 & 0.0238 & 4.36 \\
\hline COD & 0.8603 & 0.1134 & 20.75 \\
\hline AN & 0.6120 & 0.3617 & 66.2 \\
\hline TSS & 0.9289 & 0.0448 & 8.2 \\
\hline PH & 0.9729 & 0.0008 & 0.15 \\
\hline Total & 5.2957 & 0.5464 & 100 \\
\hline
\end{tabular}

Soil erosion is one of the causes of the occurrence of TSS concentration being higher. This is because land erosion is one of the most complex problems that is hard to predict especially for tropical areas with high rainfall $[18,19]$. When the sediment lifting process cannot be overcome, it will bring various problems to the care and management of the river. Among the consequences is that the river water becomes turbid, the water is not neutral, removes an unpleasant odor and color [18]. In addition, the TSS parameter concentration also increases due to external factors brought about by rainwater runoff [20-22]. In addition, anthropogenic activity such as municipal, industrial, aquaculture and aquaculture also contributed to the occurrence of TSS concentration $[23,16,17]$. This is evident when a high concentration of TSS in Terengganu River Basin is $48.03 \%$. This is due to the presence of sand mining activities around the Nerus River which may cause the riverbed to be loose and easily eroded. The rate of erosion can be controlled when the stable method of forest canopy is carried out. This is because this method can reduce surface erosion. The intercepted process is a layered layer of canopy which acts as a filtration thus reducing soil erosion during rainfall [14]. Therefore, high potential activities that cause the management of water resources in the Terengganu River Basin deteriorate must be controlled and monitored systematically.

Based on the DOE-WQI computational value (Table 3), the waters of the Terengganu River Basin from the upstream to downstream of the river are classified as class III, at a contaminated level. In this case, all stations show WQI levels not too low than $60 \%$ which are ideal for recreational activities where body contact is still safe. However, there is the treatment required to prevent the river's water quality to become worse. In this case, management and control methods should be carried out to prevent the deterioration of river water quality as a means of conservation. The results showed that low water quality was at downstream stations and in the middle stream. Downstream and central areas have low water quality because the area is close to anthropogenic activities such as industrialization, agriculture, sand mining and residential areas (WQ1 until WQ14). In contrast, high river water quality is at the head of the river where it is near the Kenyir Dam.

Table 3: Water Quality Index of Terengganu River Basin at the 29 Stations 


\begin{tabular}{|c|c|c|}
\hline $\begin{array}{c}\text { Streaming } \\
\text { Station (WQ) }\end{array}$ & $\begin{array}{c}\text { Average } \\
\text { Value WQI }\end{array}$ & $\begin{array}{c}\text { Class } \\
\text { (I, II, III and IV) }\end{array}$ \\
\hline 1 & 60.576 & III \\
\hline 2 & 67.164 & III \\
\hline 3 & 71.358 & III \\
\hline 4 & 70.288 & III \\
\hline 5 & 71.888 & III \\
\hline 6 & 70.173 & III \\
\hline 7 & 65.706 & III \\
\hline 8 & 59.289 & III \\
\hline 9 & 71.019 & III \\
\hline 10 & 73.324 & III \\
\hline 11 & 73.759 & III \\
\hline 12 & 73.531 & III \\
\hline 13 & 74.228 & III \\
\hline 14 & 65.866 & III \\
\hline 15 & 74.210 & III \\
\hline 16 & 74.434 & III \\
\hline 17 & 74.410 & III \\
\hline 18 & 73.380 & III \\
\hline 19 & 74.054 & III \\
\hline 20 & 73.134 & III \\
\hline 21 & 74.569 & III \\
\hline 22 & 73.741 & III \\
\hline 23 & 73.316 & III \\
\hline 24 & 74.757 & III \\
\hline 25 & 74.327 & III \\
\hline 26 & 74.130 & III \\
\hline 27 & 74.281 & III \\
\hline 28 & 72.885 & III \\
\hline 29 & 73.731 & III \\
\hline
\end{tabular}

\subsection{Recommendation of Water Quality Management in Terengganu River Basin}

Based on the studies conducted, the cause of water quality in the Terengganu River Basin was deteriorating. Therefore, there are several steps for water resources management in Terengganu River Basin. Among them is settlement of land use change. In this case, activities involving land use changes such as agriculture, industrial, waste disposal and sand mining, especially in the Terengganu River Basin, should be systematically controlled as to establish legal control to control land use activities [3, 24, 25]. Mitigation is also one of the steps in improving the management of water resources in Terengganu River Basin. In this race the developer must play an important role in the success of gation method. When sediment problems are not well $\mathrm{m}$ will disrupt the water resource management process and economic, social and human well-being especially thosi the Terengganu River Basin area to be affected for a [18, 26-28].

The next step is through the River Water Quality Monit gram. The program aims are intended for water resou agement such as improving river water quality, detectin and identifying sources of pollution. This program has 1 aged by Environment Malaysia Sdn.Bhd (ASMA). In tl there are 920 manual water quality monitoring statios throughout the river basin in Malaysia. The main river lution parameters in Malaysia are TSS [29]. The TSS pa to determine the quality status of the Terengganu $\mathrm{Ri}$ either clean, medium, contaminated or contaminated al classified into Class I, II, III, IV and V based on the W( NWQS [30-32]. Minimizing wastes is one of the most a steps in managing water resources in river basins. In th can be done by reducing the concentration and volume especially industrial activity through resource control cling programs. One of the possible approaches is to bui treatment plant and domestic wastewater in the industr treated water can be reused for cleaning machines and $n$ Whereas, the water to be drained into the river basir treated before it is discharged into the river basin and it : the standards set by the Environmental Quality Act 1974
The erosion of a cliff is a naturally occurring corrosion that results from gravitational force. This gravitational force will result in high pressure resulting in erosion of the cliff [34-36]. When this erosion is not controlled it will cause trees around the riverbed to fallen and thus increase the amount of TSS. In this case, the construction of the walls is one of the steps to reduce erosion from occurring. The wall was constructed using a gabion structure or known as a stone cage. Additionally, through the use of Geographic Information System (GIS) in water resource management. This system is one of the systems that store information in the form of thematic maps. In this case, the GIS system is able to disclose all required information specifically [33]. For example, the GIS system will show all industries adjacent to the river basins. This can, in no way, enable the authorities to track industries that waste untreated wastes into rivers that cause river water quality to decline. At the same time, using the GIS system, it is able to improve the efficiency of water resources management [37].

The management of water resources in other river basins is through legal means by monitoring or monitoring closely. In this case, authorities such as the Drainage and Drainage Department (DID) must play an important role, for example directing all industries to install industrial waste filter systems. This is to prevent the untreated waste from being channeled directly into the river. In addition, the community must also be familiar with water resource management as it supports every program or activity held in relation to the management of river resources, especially programs involving river water quality.

For example, One State One River Program. This program is an initiative to preserve the quality of river water from polluted. In this case, every management undertaken must follow the guidelines laid down by integrated river basin management (IRBM), using the best management methods such as prevention, rehabilitation and river management [38]. The objective of this program is to achieve clean and valuable river with water quality in Class II by 2015 [39]. In addition, the program is also to reduce the number of river pollution, river died and abandoned to clean, living, natural river and support river life. Therefore, the program is suitable for the Terengganu Basin to control the Terengganu River from contaminated.

\section{Conclusion}

In conclusion, the study proves that the WQI value for downstream to the middle of the river is higher than the actual level of WQI. Terengganu River Basins in downstream and central polluted rivers may be caused by waste and effluent products derived from development, housing, sand mining and agriculture activities. Based on NWQS, the most measured parameter is still in class I from upstream to downstream station. In this regard, various anthropogenic activities have resulted in significant changes in the quality of river water quality. The results presented here provide a basic reference on the monitoring of Sungai Terengganu basin in the future. Furthermore, water resource management, especially in river basins is an important aspect to be improved and observed. The results showed that the water quality in the Terengganu River Basin was affected and deteriorated mainly in the downstream and central areas. This is due to several activities such as waste disposal, municipal, industrial and untreated agriculture into the river system.

Additionally, there are other activities that cause the quality of the river to be affected as aquaculture and sand mining activities that cause TSS concentration to be higher. In this case, all parties should work together in maintaining the quality of water especially in river basins. Various initiatives have been implemented by the government in managing water resources. Among the initiatives undertaken by the government are the "love of our river" campaign that involves all the villagers and towns in each state. The campaign is aimed at ensuring that every community is responsible for the care and maintenance of the river. At the same time, authorities such as the Department of Environment (DOE) 
should play an important role as to monitor whether in the industries or river water regularly so that the water resources management in the river basin can run well and provide quality water to community. Subsequently, in this study we have proposed several steps in the management of water resources in the Terengganu River Basin. This is to ensure that the Terengganu River Basin is free of water pollution and can provide quality water to the community.

\section{Acknowledgement}

The authors acknowledge to UniSZA for Scholarship under research grants: UniSZA/2017/SRGS/17) - R0019-R017. Special thanks are also dedicated to Faculty of Applied Social Science, Fakulti Sains Sosial Gunaan (FSSG) and Department of Statistics Malaysia give permission to use the research facilities, provided the secondary data and supporting in this research.

\section{References}

[1] Alam, M., Siwar, C., Murad, M., Molla, W., Islam, R., \& Toriman, M E. (2010). Sociaeconomic profile of farmer in Malaysia: Study on integrated agricultural development area in north-west Selangaor. Agricultural Economics and Rural Development, 7(2): 249-265

[2] Toriman, M. E. (2010). Assessing environmental flow modeling for water resources management: A case of sungai (river) Pelus, Malaysia. Nature and Science, 2(8): 74-81.

[3] Toriman, M. E., Kamarudin, M. K. A., Idris, M. H., Gasim, M. B., \& Jamil, N. R. (2008). Masalah sedimentasi dan penyelesaiannya melalui kaedah pengurusan persekitaran: Satu kajian kes di Sungai Chini, Pahang. E-Bangi: Jurnal Sains Sosial dan Kemanusiaan, 3(3): 1-14.

[4] Wahid, N.A., Abustan, I., Mui, L.M \& Yong, L.H. (2006). Water saving exploring pinang consumer's knowledge, actual behavior and intention. Proceedings of the National Conference-Water for Sustainable Development towards a Developed Nation by 2020.

[5] Gupta, A. K., Gupta, S. K., \& Patil, R. S. (2003). A comparison of water quality indices for coastal water. Journal of Environmental Science and Health, Part A, 38(11): 2711-2725.

[6] Kannel, P. R., Lee, S., Lee, Y., Kanel, S. R., \& Khan, S. P. (2007) Application of water quality indices and dissolved oxygen as indicators for river water classification and urban impact assessment. Environmental Monitoring and Assessment, 132(1-3): 93-110.

[7] Said, A., Stevens, D. K., \& Sehlke, G. (2004). An innovative index for evaluating water quality in streams. Environmental Management, 34(3): 406-414.

[8] Taner, M. U, Ustun, B., \& Erdincler, A. (2011). A simple tool for the assessment of water quality in polluted lagoon systems: A case study for Kuçukçekmece Lagoon, Turkey. Ecological Indicators, 11(2): 749-756.

[9] Toriman, M. E., Mokhtar, M., Gasim, M. B., Syed Abdullah, S. M. Jaafar, O \& Abd Aziz, N. A. (2009). Water resources study and modeling at North Kedah: A case of Kubang Pasu and Padang Terap water supply schemes. Research Journal of Earth Sciences, 1(2): 35-42

[10] Juahir, H., Zain, S. M., Mokhtar, M. B., Toriman, M. E., Jalaludin, Z. \& Jan, I. K. M. (2008). The use of chemometrics analysis as a costeffective tool in sustainable utilisation of water resources in the Langat River catchment, Malaysia. American-Eurasian Journal of Agricultura and Environmental Sciences, 4(2): 258-265.

[11] Suratman, S., Sailan, M. M., Hee, Y. Y., Bedurus, E. A., \& Latif, M. T. (2015). A preliminary study of water quality index in Terengganu River basin, Malaysia. Sains Malaysiana, 44(1): 67-73.

[12] Wahab, N. A., Kamarudin, M. K. A., Toriman, M. E., Juahir, H., Gasim, M. B., Rizman, Z. I., \& Damayanti, P. P. (2018). Climate changes impacts towards sedimentation rate at Terengganu River, Terengganu, Malaysia. Journal of Fundamental and Applied Sciences, 10(1S): 33-51.

[13] Kamarudin, M. K. A., Toriman, M. E., Wahab, N. A., Rosli, H., Ata, F. M., \& Faudzi, M. N. M. (2017). Sedimentation study on upstream reach of selected rivers in Pahang river basin, Malaysia. International Journa on Advanced Science, Engineering and Information Technology, 7(1) $35-41$.

[14] Toriman, M. E., \& Md. Nor, S. (2006). An analysis of rain interception on the selected experimental plot of Pangkor hill reserved forest. Journal Wildlifeand National Park, 22(2): 169-178.

[15] Gasim, M. B., Toriman, M. E., Abd. R. S., Islam, M. S., Tan, C. C., \& Juahir, H. (2006). Hydrology and water quality assessment of Tasik Chini's feeder rivers, Pahang Malaysia. Geografia, 3(3), 1-16.

[16] Bordalo, A. (2001). Water quality and uses of the Bangpakong River (Eastern Thailand). Water Research, 35(15): 3635-3642.
[17] Suratman, S., Awang, M., Loh, A.L. \& Mohd Tahir, N. (2009). Water quality index study in Paka River basin, Terengganu (in Malay). Sains Malaysiana, 38: 125-131.

[18] Toriman, M. E., Kamarudin, M. K. A., Aziz, N. A. A., Din, H. M., Ata, F. M., Abdullah, N. M., \& Abdullah, N. W. (2012). Pengurusan sedimen terhadap sumber air bersepadu: Satu kajian kes di Sungai Chini, Pekan Pahang. E-Bangi: Jurnal Sains Sosial Dan Kemanusiaan, 7(1): 267-283.

[19] Kamarudin, M. K. A., Toriman, M.E., Idris, M., Juahir, H., Azid, A., Gasim, M. B., Umar, R., Endut, A., Mokhtar, M., Khalit, S. I., Ismail, A., Yaakob, N. H. M., \& Rwoo, M. A. (2016). Environmental management on natural lake using sediment and hydrology hydraulic models. Malaysian Journal of Applied Sciences, 1(2): 9-26.

[20] Jonnalagadda, S., \& Mhere, G. (2001). Water quality of the Odzi River in the eastern highlands of Zimbabwe. Water Research, 35(10): 23712376

[21] Rossi, L., Krejci, V., Rauch, W., Kreikenbaum, S., Fankhauser, R., \& Gujer, W. (2005). Stochastic modeling of total suspended solids (TSS) in urban areas during rain events. Water Research, 39(17): 4188-4196.

[22] Suratman, S., Mohd Tahir, N., Lee, C. Y., \& Siti Rohayu, A. R., (2006) Monsoon effects on water quality in Besut River Basin, Terengganu (in Malay). Malay. J .Anal. Sci., 10: 143-148.

[23] Atkinson, C. L., Golladay, S. W., \& First, M. R. (2011). Water quality and planktonic microbial assemblages of isolated wetlands in an agricultural landscape. Wetlands, 31(5): 885-894.

[24] Kamarudin, M. K. A., Toriman, M. E., Rosli, M. H., Juahir, H., Aziz, N. A. A., Azid, A., \& Sulaiman, W. N. A. (2015). Analysis of meander evolution studies on effect from land use and climate change at the upstream reach of the Pahang River, Malaysia. Mitigation and Adaptation Strategies for Global Change, 20(8): 1319-1334.

[25] Ata, F. M., Kamarudin, M. K. A., Toriman, M. E., Zin, M. S. M., Sulaiman, N. H., Wahab, N. A., \& Saad, J. M. (2016). Klasifikas sedimen menggunakan teknik envirometrik: Satu kajian kes di Sungai Pahang, Malaysia. Malaysian Journal of Analytical Sciences, 20(5): $1171-1180$

[26] Toriman, M. E., Pereira, J. J., Gasim, M. B., Sharifah Mastura, S. A., \& Abdul Aziz, N. A. (2011). Issues of climate change and water resources in Peninsular Malaysia: The case of northern Kedah. Arab World Geographer, 12(1-2): 87-94.

[27] Wahab, N. A., Kamarudin, M. K. A., Gasim, M. B., Umar, R., Ata, F. M., \& Sulaiman, N. H. (2016). Assessment of total suspended sediment and bed sediment grains in upstream areas of Lata Berangin, Terengganu. International Journal on Advanced Science, Engineering and Information Technology, 6(5): 757-763.

[28] Nalado, A. M., Kamarudin, M. K. A., Wahab, N. A, Rosli, M. H., \& Saudi, A. S. M. (2017). Assessment of individual water quality index parameter in Terengganu River, Malaysia. Journal Fundamental Appllied Science, 9(2S): 430-442.

[29] Jahi, J. (2000). Pengurusan persekitaran di Malaysia: Isu dan cabaran. Program pengurusan persekitaran. Universiti Kebangsaan Malaysia.

[30] Idris, M., \& Kutty, A. A. (2005). Trends of physicochemical water quality in Tasik Chini. Khazanah Tasik Chini. Bangi. Universit Kebangsaan Malaysia Publisher.

[31] Arman, N. Z., Said, M. I. M., \& Azman, S. (2013). Anthropogenic influences on aquatic life community and water quality status in Mengkibol River, Kluang, Johor, Malaysia. Journal of Applied Sciences in Environmental Sanitation, 8(3): 151-160.

[32] Rashid, S. A. A., Gasim, M. B., Toriman, M. E, Juahir, H., Kamarudin, M. K. A., Azid A., \& Abd Aziz, N. A. (2014). Water quality deterioration of Jinjang River, Kuala Lumpur: Urban risk case water pollution. Arab World Geographer, 16(4): 349-362.

[33] Abdullah, M. A., \& Saad, S. (2002). Impak pembangunan terhadap kualiti air di hilir Sungai Kerian, Perak. Proceedings of the Seminar Kebangsaan Sains, Teknologi dan Sains Sosial, pp. 1-10.

[34] Strahler, A. N. (1978). Geografi fizikal. John Wiley and Sons.

[35] Zhang, X., \& Walling, D. E. (2005). Characterizing land surface erosion from cesium-137 profiles in lake and reservoir sediments. Journal of Environmental Quality, 34(2): 514-523.

[36] Toriman, M. E., Ata, F. M., Kamarudin, M. K. A., \& Idris, M. (2013). Bed-load sediment profile and effect of river bank erosion on river cross-section. American Journal of Environmental Sciences, 9(4): 292 300

[37] Mohamed, A. F. (1999). Penggunaan Sistem Maklumat Geografi (GIS) di dalam program pengawalan pencemaran industri. Salam LESTARI.

[38] Chuan, A. S., Weng, C. N., Mansor, M., Samat, N., \& Hin, L. (2013). Cabaran dalam kemampanan pengurusan sungai di Malaysia. Proceedings of the Seminar Serantau Ke-2 Pengurusan Persekitaran di Alam Melayu, pp. 1-11.

[39] Jabatan Pengairan dan Saliran Malaysia. (2012). Pengurusan SungaiPengurusan Lembangan Sungai Bersepadu (IRBM). fromhttp://www.water.gov.my/ourservicemainmenu252/rivermanagementmainmenu278/activitiesmainmenu265?Lang=my $\&$ start $=2$. 